\title{
A method to feed individual bees (Hymenoptera: Apiformes) known amounts of pesticides
}

\author{
Edith LADURNER ${ }^{\mathrm{a}}$, Jordi BOSCH${ }^{\mathrm{b} *}$, Stefano MAINI ${ }^{\mathrm{a}}$, William P. KEMP ${ }^{\mathrm{c}}$ \\ a Dipartimento di Scienze e Tecnologie Agroambientali, Università di Bologna, 40126 Bologna, Italy \\ b Biology Department, Utah State University, Logan, UT 84322-5310, USA \\ ${ }^{c}$ USDA-ARS, Bee Biology \& Systematics Laboratory, Logan, UT 84322-5310, USA
}

(Received 10 October 2002; revised 1 February 2003; accepted 16 May 2003)

\begin{abstract}
We devised a simple method ("flower") to feed bees individually, and compared it with two other methods commonly used ("film canister" and "glass vial"). We tested the three methods on two solitary species, Osmia lignaria and Megachile rotundata, and one social species, Apis mellifera, under four different light regimes (natural, artificial, plant growth and darkness). The flower method was the most effective for all three bee species: $90-95 \%$ of the bees fed under natural light, 80-95\% under artificial light, $75-100 \%$ under plant growth light, and $45-70 \%$ in darkness. Percent success was $0-50 \%$ with the film canister method, and 0-60\% with the glass vial method. The flower method may allow more comprehensive future evaluation of pesticide effects on bees.
\end{abstract}

oral toxicity test / individual feeding / Osmia lignaria / Apis mellifera / Megachile rotundata

\section{INTRODUCTION}

Bee populations are often exposed to pesticide treatments in both natural and agricultural ecosystems (Kevan, 1975; Crane and Walker, 1983; Johansen and Mayer, 1990; Peach et al., 1993), and insecticide poisoning is considered one of the main causes of bee population declines worldwide (Dias and Raw, 1999; Tepedino and Ginsberg, 2000). Given the ecological and economic importance of bees as pollinators of wild flowers and cultivated plants (Kevan, 1991; Southwick and Southwick, 1992), it is surprising that our knowledge on bee toxicity is so fragmentary and mostly restricted to one species, the honey bee, Apis mellifera L. (Apidae) (Johansen and Mayer, 1990). Information on pesticide toxicity to non-Apis bees is dismally scarce, and limited to a handful of species managed for crop pollination (review in Taséi, 2002). A common first step in bee toxicity studies is the establishment of $\mathrm{LD}_{50}$ (median lethal dose) values, i.e. the dose, expressed in $\mu \mathrm{g}$ of active ingredient per insect, inducing 50\% mortality following application (contact or oral) of measured amounts of active ingredients or commercial pesticide formulations. The methods used for determining $\mathrm{LD}_{50}$ values on $A$. mellifera are defined by official guidelines, both in Europe and in the USA (US EPA, 1996; OEPP/EPPO, 2001; Cluzeau, 2002). Methods used to study contact toxicity in $A$. mellifera can be easily applied to other species. However, in studies of oral toxicity in $A$. mellifera a common feeder is provided to a group of workers assuming that, through trophallaxis, all individuals will receive similar doses of test solution (OEPP/EPPO, 2001). Group feeding is not applicable to most other bee species, which do not perform trophallaxis and thus require individual feeding. In fact,

\footnotetext{
* Corresponding author: Nomada@biology.usu.edu
} 
oral tests on non-Apis bees are rarely conducted because individual feeding is considered time consuming (Felton et al., 1986).

In 2002, we initiated a study on the effect of pesticide sprays on the solitary bee Osmia lignaria Say (Megachilidae). We tried to feed individual $O$. lignaria known amounts of sugar solution using some of the methods available from the literature (Taséi, 2002), but our success rate (percent individuals that would feed) was very low. Thus, we devised a new method, which we tested in comparison to the two most commonly used methods available (Johansen et al., 1984; van der Steen et al., 1996; Bortolotti et al., 2002; Patetta et al., 2002). All three methods were tested on two solitary bee species $O$. lignaria and Megachile rotundata (Fabricius) (Megachilidae), and the social bee A. mellifera. All three species are used as crop pollinators (Richards, 1984; Free, 1993; Bosch and Kemp, 2001), and thus are frequently exposed to pesticides.

\section{MATERIALS AND METHODS}

Apis mellifera workers were captured in the morning at the entrance of a hive and brought to the laboratory, where they were chilled for a maximum of $30 \mathrm{~min}$ at $4{ }^{\circ} \mathrm{C}$ prior to being assigned to the different feeding methods. Osmia lignaria and $M$. rotundata wintering females within their cocoons were incubated until emergence at $25^{\circ} \mathrm{C}$ and $29^{\circ} \mathrm{C}$, respectively. Upon emergence, females were transferred to a holding cage $(40 \times 30 \times 30 \mathrm{~cm})$ to allow them to deposit the meconium. Females were starved overnight and then assigned to the different feeding methods. No chilling was necessary for either $O$. lignaria or $M$. rotundata.

We used the following three individual feeding methods: (1) Film canister method (after van der Steen et al., 1996; Bortolotti et al., 2002; Patetta et al., 2002). Bees were individually transferred to black film canisters $(3 \mathrm{~cm}$ diameter, $5 \mathrm{~cm}$ height) with a small hole drilled on the side, near the base. The test solution was pipetted onto a microscope slide next to the hole. (2) Glass vial method (after Johansen et al., 1984). Bees were individually transferred to $12-\mathrm{mL}$ glass vials with plastic snap caps. The test solution was injected into a segment of plastic tubing (length $15 \mathrm{~mm}$, inside diameter $2.9 \mathrm{~mm}$ ), fitted snugly into the plastic snap caps. (3) Flower method (Fig. 1). A tiny plastic ampoule (inside diameter $2 \mathrm{~mm}$, outside diameter $3 \mathrm{~mm}$, height $5 \mathrm{~mm}$ ) was inserted into the calyx of a flower, whose reproductive column had been
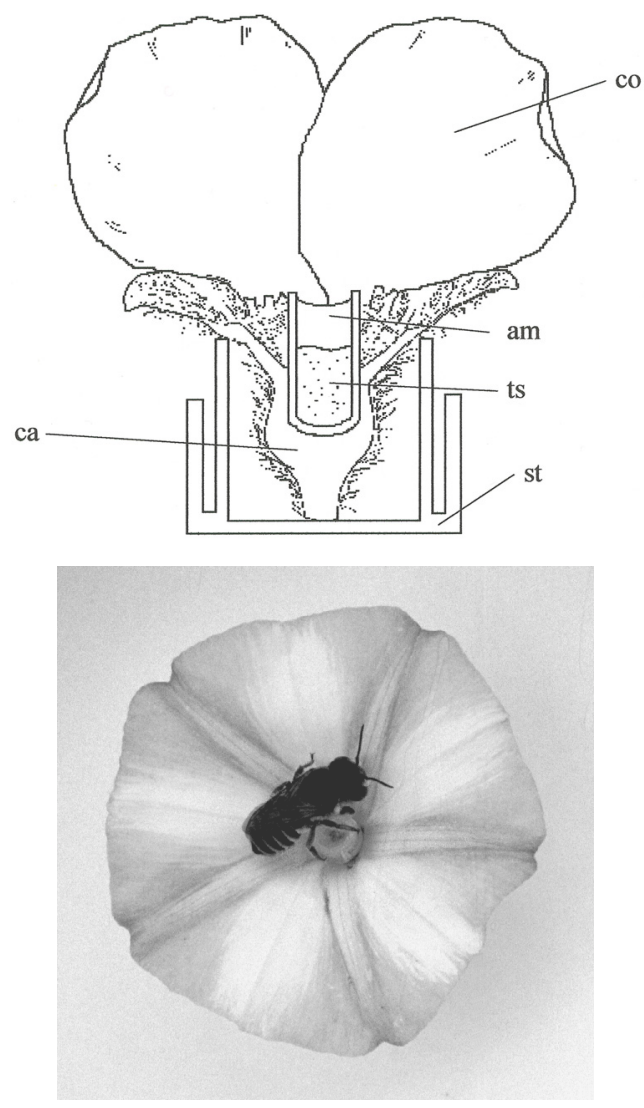

Figure 1. Feeding unit for the flower method. Cross-section drawing and photograph of Megachile rotundata female on test flower. The plastic ampoule containing the test solution can be seen at the center of the corolla. am: ampoule. ca: flower calyx. co: flower corolla. st: stopper (flower holder). ts: test solution.

previously removed with a pair of forceps. The plastic ampoule was built by approaching one tip of a 5-mm section of polyethylene tubing to a flame or some other heat source. The heat caused the polyethylene tip to melt, sealing the tubing orifice. Because the polyethylene never actually touched the heat source, no charring occurred, and ampoules had no obvious odor. The test solution was pipetted into the ampoule. Flowers and bees were individually housed in ice cream cups made of waxed cardboard ( $8 \mathrm{~cm}$ diameter, $5 \mathrm{~cm}$ height) covered with a plastic Petri dish lid. Flowers were positioned on an inverted glass vial stopper. A wire mesh screen insert (mesh size $2 \times 1 \mathrm{~mm}$ ) in the Petri dish lid provided adequate aeration. To facilitate flower manipulation, we used large, actinomorphic flowers with open corollas. In preliminary trials, we tested two or 
Table I. Percent feeding success in Osmia lignaria females, Megachile rotundata females, and Apis mellifera workers offered $10 \mu \mathrm{L}$ of sugar solution using three individual feeding methods under four light regimes $(n=20$ per species/feeding method/light regime).

\begin{tabular}{|c|c|c|c|c|c|}
\hline \multirow[b]{2}{*}{ Bee species } & \multirow[b]{2}{*}{$\begin{array}{l}\text { Feeding } \\
\text { method }\end{array}$} & \multicolumn{4}{|c|}{ Light regime } \\
\hline & & $\begin{array}{c}\text { Natural } \\
\text { light }\end{array}$ & $\begin{array}{c}\text { Cool-white } \\
\text { light }\end{array}$ & $\begin{array}{c}\text { Gro-Lux } \\
\text { light }\end{array}$ & Darkness \\
\hline \multirow[t]{3}{*}{ O. lignaria } & Film canister & 5 & 0 & 0 & 5 \\
\hline & Glass vial & 5 & 0 & 0 & 10 \\
\hline & Flower & 90 & 80 & 75 & 70 \\
\hline \multirow[t]{3}{*}{ M. rotundata } & Film canister & 15 & 25 & 10 & 15 \\
\hline & Glass vial & 20 & 60 & 25 & 40 \\
\hline & Flower & 95 & 90 & 100 & 70 \\
\hline \multirow[t]{3}{*}{ A. mellifera } & Film canister & 35 & 50 & 30 & 20 \\
\hline & Glass vial & 45 & 50 & 60 & 15 \\
\hline & Flower & 95 & 95 & 80 & 45 \\
\hline
\end{tabular}

more flowers per bee species, including cherry (Prunus avium L.), apple (Malus domestica Borkh), morning glory (Convolvulus arvensis L.) and periwinkle (Vinca minor L.). All flowers in these preliminary trials yielded similar results. In the actual experiments we used cherry flowers for the earlyflying $O$. lignaria and morning glory flowers for the later-flying $M$. rotundata and A. mellifera. A trained technician could prepare 100 test flowers in 40 minutes.

In all three methods, a $10-\mu \mathrm{L}-$ drop of test solution $25 \%$ volume of sucrose to $75 \%$ volume of water) was offered to the bee for one hour. We tested each method under four different light regimes: (1) Natural light. Feeding units placed outdoors (on sunny to partially-cloudy days); (2) Artificial light 1 . Feeding units placed in an incubator with two $15 \mathrm{~W}$ Cool White Sylvania ${ }^{\circledR}$ fluorescent tubes (wavelength peaks at 405, 430, 545 and $575 \mathrm{~nm}$ ) placed $15 \mathrm{~cm}$ above the feeding units; (3) Artificial light 2. Feeding units placed in an incubator with two 20W Gro-Lux/Aquarium Standard Sylvania ${ }^{\circledR}$ fluorescent tubes (usually used to help plant growth; wavelength peaks at 460, 545, 630 and $660 \mathrm{~nm}$ ) placed $15 \mathrm{~cm}$ above the feeding units; (4) Darkness. Feeding units placed in an incubator with no light. We tested darkness because current guidelines for group feeding toxicology assays are usually conducted in darkness (Arzone and Vidano, 1980; OEPP/EPPO, 2001). Temperatures during all tests (including those outdoors) were $22 \pm 2{ }^{\circ} \mathrm{C}$ for $O$. lignaria and $25 \pm 2{ }^{\circ} \mathrm{C}$ for $M$. rotundata and $A$. mellifera. We used a lower temperature for $O$. lignaria because this spring-flying bee is active at lower temperatures than M. rotundata or A. mellifera (Burril and Dietz, 1981; Lerer et al., 1982; Bosch and Kemp, 2001).
Sample sizes were 20 individuals of each species (workers in A. mellifera, females in O. lignaria and $M$. rotundata) per feeding method/light regime. We analyzed the proportion of feeding bees as a function of feeding method and light regime. Because different bee species were tested under different temperatures and with different flowers, we analyzed the results of each species separately. Due to the number of cells with frequencies of $<5$ for one of the species $(O$. lignaria, Tab. I), we attempted to fit an exact Logit model using LogXact (Version 5.0). However, the computational size was too large for this exact method to work (even on a sufficiently equipped computer). In addition, the complete separation of the data prevented the computation of Likelihood Ratio and Wald test statistics. Therefore, because the structure of the $O$. lignaria data prevented the use of an exact test, we used an asymptotic Logit model (GENMOD procedure, SAS Institute Inc., 1989; Allison, 1999). Because of the pronounced pattern of the results (O. lignaria was the species for which differences among feeding methods were most extreme), it is unlikely that the use of this statistical analysis would compromise our interpretations.

\section{RESULTS}

The flower method was, by far, the most effective for all three bee species (Tab. I): $90-95 \%$ of the bees fed under natural light, 80-95\% under Cool White fluorescent tubes, 75-100\% under Gro-Lux fluorescent tubes, and $45-70 \%$ in darkness. All bees that fed with the flower method consumed all $10 \mu \mathrm{L}$ of the test solution. Percent success was 0-60\% with 
Table II. Results of Logit analysis of feeding success in Osmia lignaria females, Megachile rotundata females, and Apis mellifera workers offered $10 \mu \mathrm{L}$ of sugar solution using three feeding methods under four light regimes.

\begin{tabular}{lcccc}
\hline Species & Source & $\mathrm{df}$ & $X^{2}$ & $\mathrm{P}$ \\
\hline O. lignaria & method & 2 & 166.2 & $<0.0001$ \\
& light & 3 & 6.87 & 0.076 \\
& method $\times$ light & 6 & 7.10 & 0.312 \\
\hline M. rotundata & method & 2 & 107.66 & $<0.0001$ \\
& light & 3 & 5.59 & 0.133 \\
& method $\times$ light & 6 & 14.36 & 0.026 \\
\hline A. mellifera & method & 2 & 39.97 & $<0.0001$ \\
& light & 3 & 44.16 & $<0.0001$ \\
& method $\times$ light & 6 & 11.29 & 0.080 \\
\hline
\end{tabular}

the glass vial method, and 0-50\% with the film canister method. The results of the Logit analysis are shown in Table II. Feeding method had a significant effect on feeding success in all three species. Light regime was only significant in A. mellifera, with fewer bees feeding in the dark compared to the other regimes, and there was a weak but significant interaction between feeding method and light regime in $M$. rotundata.

\section{DISCUSSION}

The film canister method has been used on bumblebees, Bombus terrestris L. (Apidae) (van der Steen et al., 1996; Bortolotti et al., 2002; Patetta et al., 2002), and van der Steen et al. (1996) reported success rates around $83 \%$. The glass vial method has been used on A. mellifera, M. rotundata, and Nomia melanderi Cockerell (Halictidae) (Johansen et al., 1984), but information on feeding success was not reported. We observed that unless relative humidity was kept above $80 \%$ during the test, the droplet on the glass slide of the film canister units would evaporate very quickly, and the precise dose of solution taken by the bee could thus not be determined. No significant evaporation occurred with the flower and the glass vial methods. With these two methods, it is possible to observe whether all the solution has been consumed, and eventually extract and measure the amount of solution left with dis- posable microcapillary pipettes. This allows for more accurate establishment of $\mathrm{LD}_{50}$ values, and provides information on distastefulness/repellency (OEPP/EPPO, 2001). In the flower method, flowers would sometimes tip when bees crawled upon them, but the test solution did not spill.

It might be argued that extending exposure time of bees to the feeding units could improve success rates. Johansen et al. (1984) left bees in the feeding glass vials for three hours, but found that most bees fed within 1 hour. We observed that, with all three feeding methods, bees would usually feed within 30 minutes or not at all. Furthermore, current guidelines discourage individual confinement of A. mellifera for more than one hour (Felton et al., 1986; OEPP/EPPO, 2001). To standardize procedures, it would be better to use similar conditions with all bee species. Because artificial and natural light tests yielded similar results, we recommend the use of artificial light.

A common problem in bee toxicology studies is the reluctance of bees to feed on solutions containing chemicals. A recent review points out that repellency is less of a problem in field trials than in laboratory tests, probably because the attractiveness of the flowers overrides the repellency of the chemical application (Thompson, 2003; see also Naumann et al., 1994). Using the flower method, chemicals such as Captan and Neem known to be repellent when dissolved in sucrose (Solomon and Hooker, 1989; Naumann et al., 1994) were readily ingested by $A$. mellifera and $O$. lignaria, even at near-saturation concentrations (E.L., unpublished).

With the flower method, a source of flowers not treated with chemicals needs to be secured throughout the study. Two of the flowers that we tried, $V$. minor and $C$. arvensis were available in large numbers and for long periods (more than two months) in gardens in spring and summer, respectively. In preliminary, offseason, trials we used flowers grown in greenhouses. The flower method is more laborintensive than the other two methods tested. However, because it is much more efficient, it actually saves time since fewer feeding units need to be prepared and fewer bees need to be collected and/or reared. This is especially important when studying species that cannot be obtained in large numbers. As mentioned, 
as many as 100 flowers can be prepared in 40 minutes. To further save time, we tried to deposit the droplet of sugar solution directly on the flower corolla (without the polyethylene ampoule). However, at least when systemic pesticides were added to the sugar solution, the droplet was partially absorbed by the flower tissues. In a subsequent study, the flower method (with the ampoule and under artificial light) was used to assess the toxicity of several pesticides to O. lignaria and A. mellifera. Success (feeding) rates were $97.7 \%$ for the first species, and $88.2 \%$ for the second $(\mathrm{n}=$ 871 and 755, respectively) (E.L., unpublished data). In conclusion, the flower method is a simple, highly effective procedure that could help simplify and standardize oral toxicity tests on a diversity of bee species in the laboratory. To further standardize procedures, future studies should investigate the possibility of substituting natural flowers by artificial flowers properly colored and scented.

\section{ACKNOWLEDGEMENTS}

We are grateful to S. Kalaskar and G. Trostle (USDA, Logan) for their assistance, to L. Bortolotti (INA, Bologna) and J.-N. Taséi (INRA, Lusignan) for reviewing the manuscript, and to S. Durham and C. Corcoran (Utah State University, Logan) for statistical advise. This study was partially supported by a Ph.D. scholarship from the University of Bologna to E. L.

Résumé - Méthode pour administrer individuellement aux abeilles (Hymenoptera, Apiformes) une quantité définie de pesticides. Les études en laboratoire sur l'action des pesticides sur les abeilles écartent souvent les tests de toxicité orale à cause de la difficulté d'administrer des quantités définies de solutions à tester. Les études sur l'Abeille domestique (Apis mellifera L.) reposent sur des méthodes de nourrissement de groupe et considèrent que des quantités sensiblement égales de solution sont ingérées par chaque ouvrière à travers les échanges de nourriture (trophallaxie). Néanmoins la plupart des abeilles (s.l.) ne pratiquent pas la trophallaxie. Nous avons mis au point une méthode simple (la méthode "de la fleur») pour nourrir des abeilles individuellement et l'avons comparée à deux autres méthodes couramment employées (les méthodes de «la boîte pour pellicule photo » et celle du «flacon en verre »). Nous avons testé les 3 méthodes sur 2 abeilles solitaires, Osmia lignaria Say et Megachile rotundata (Fabricius) (Megachilidae), et sur une espèce sociale, A. mellifera, sous 4 régimes de lumière différents (lumière naturelle, tubes fluorescents blanc froid, tubes fluorescents Gro-Lux et obscurité). Dans la méthode de la fleur, les abeilles étaient confinées individuellement dans une coupe à glace. On leur donnait une fleur dont le pistil avait été remplacé par une fine ampoule dans laquelle la solution à tester était pipetée (Fig. 1). La méthode de la fleur a été la plus efficace chez les 3 espèces d'abeilles (Tab. I), quel que soit le type d'éclairage : 90-95\% en lumière naturelle, 80-95\% avec tubes fluorescents blanc froid, 75-100\% avec tubes fluorescents Gro-Lux et $45-70 \%$ en obscurité. Le pourcentage de succès a été compris entre 0 et $50 \%$ avec la méthode de la boîte pour pellicule photo et entre 0 et $60 \%$ avec la méthode du flacon de verre. La préparation des unités de nourrissement demandait plus de travail dans la méthode de la fleur mais avec de la pratique, on peut préparer 100 fleurs en 40 min. En raison de sa grande efficacité, la méthode peut en fait économiser du temps (en termes de récolte d'abeilles et de préparation) et du matériel animal.

\section{Osmia lignaria / Apis mellifera / Megachile rotundata / test de laboratoire / toxicité orale / nourrissement individuel}

Zusammenfassung - Eine Methode zur Fütterung von Bienen (Hymenoptera: Apiformes) mit definierten Mengen von Pestiziden. Bei Laborversuchen über die Wirkung von Pestiziden auf Bienen scheiden oft orale Toxizitätstests wegen der Schwierigkeit aus, Bienen individuell mit definierten Mengen der Testlösungen zu füttern. Versuche bei der Honigbiene, Apis mellifera L. (Apidae), beruhen auf der Fütterung einer Gruppe. Dabei wird angenommen, dass alle Bienen über Futteraustausch (Trophallaxis) etwa die gleiche Menge der Lösung aufnehmen. Die meisten Bienenarten haben jedoch keine Trophallaxis. Wir entwickelten eine einfache Methode („Blüten“ Methode), um Bienen individuell zu füttern und verglichen die Effektivität mit zwei anderen allgemein benutzten Methoden (,film canister“ und „glass vial“ Methoden). Wir testeten die 3 Methoden bei zwei solitären Arten, Osmia lignaria Say und Megachile rotundata (Fabricius) (Megachilidae), und einer sozialen Art, A. mellifera, unter 4 unterschiedlichen Lichtbedingungen (natürliches Licht, kalte weiß fluoreszierende Röhren, Gro-Lux fluoreszierende Röhren und Dunkelheit). Bei der Blütenmethode wurden Bienen individuell in einem Eiskrembecher gekäfigt. Ihnen wurden Blüten angeboten, deren Stempel entfernt und durch eine winzige Ampulle ersetzt worden war, in die die Testlösung pipettiert wurde (Abb. 1). Die Blütenmethode war bei allen 3 Bienenarten am erfolgreichsten (Tab. I): 90-95\% der Bienen, die bei natürlichem Licht gefüttert wurden, 80-95 \% bei kalt weiß fluoreszierendem Licht, $75-100 \%$ bei Gro-Lux fluoreszierendem Licht und 45-70 \% in Dunkelheit. Der prozentuale Erfolg bei der ,film canister“ Methode lag bei $0-50 \%$ und bei 
der „glass vial“ Methode bei 0-60\%. Die Anfertigung der Futtervorrichtung war bei der Blütenmethode am aufwendigsten. Nach einiger Übung kann man jedoch 100 Testblüten in 40 Minuten anfertigen und auf Grund der hohen Effektivität spart man mit dieser Methode im Endeffekt sowohl Zeit (bei Berücksichtigung der Zeit für die Sammlung von Bienen und ihrer Präparation) als auch Tiermaterial.

oraler Toxizitätstest / individuelle Fütterung / Osmia lignaria / Apis mellifera / Megachile rotundata

\section{REFERENCES}

Allison P.D. (1999) Logistic regression using the SAS System, SAS Institute Inc., Cary, NC.

Arzone A., Vidano C. (1980) Methods for testing pesticide toxicity to honey bees, Boll. Lab. Entomol. Agr. Filippo Silvestri 37, 161-165.

Bortolotti L., Porrini C., Sbrenna G. (2002) Effetti dell'imidacloprid nei confronti di Bombus terrestris (L.), Prove di laboratorio, Inf. Fitopatol. 3, 66-71.

Bosch J., Kemp W.P. (2001) How to manage the blue orchard bee as an orchard pollinator. Handbook Series, Book 5. Sustainable Agriculture Network, Beltsville, MD.

Burrill R.M., Dietz A. (1981) The response of honeybees to variations in solar radiation and temperature, Apidologie 12, 319-328.

Crane E., Walker P. (1983) The impact of pest management on bees and pollination, IBRA, Cardiff, UK.

Cluzeau S. (2002) Risk assessment of plant protection products on honey bees: regulatory aspects, in: Devillers J., Pham-Delègue M.-H. (Eds.), Honey bees: estimating the environmental impact of chemicals, Taylor \& Francis, London, pp. 42-55.

Dias B.S.F., Raw A., Imperatriz-Fonseca V.L. (1999) International pollinator initiative, the São Paulo declaration on pollinators, Ministério do Meio Ambiente, Brasília DF, http://www.bdt.fat. org.br/polinizadores/declaration (consulted on 16 September 2003).

Felton J.C., Oomen P.A., Stevenson J.H. (1986) Toxicity and hazard of pesticides to honeybees: harmonization of test methods, Bee World 67, 114-124.

Free J.B. (1993) Insect pollination of crops, 2nd ed., Academic Press, London.

Johansen C.A., Rincker C.M., George D.A., Mayer D.F., Kious C.W. (1984) Effects of Aldicarb and its biologically active metabolites on bees, Environ. Entomol. 13, 1386-1398.

Johansen C.A., Mayer D.F. (1990) Pollinator Protection: A bee and pesticide handbook, WicWas, Cheshire, CT.

Kevan P.G. (1975) Forest application of the insecticide Fenitrothion and its effect on wild bee pollinators (Hymenoptera: Apoidea) of lowbush blueberries (Vaccinium spp.) in southern New Brunswick, Canada, Biol. Conserv. 7, 301-309.

Kevan P.G. (1991) Pollination: keystone process in sustainable global productivity, Acta Hortic. 288, 103-110.

Lerer H., Bailey W.G., Mills P.F., Pankiw P. (1982) Pollination activity of Megachile rotundata (Hymenoptera: Apoidea), Environ. Entomol. 11, 997-1000.

Naumann K., Currie R.W., Isman M.B. (1994) Evaluation of repellent effects of a Neem insecticide on foraging honey bees and other pollinators, Can. Entomol. 126, 225-230.

OEPP/EPPO (2001) Revised draft of EPPO Guidelines PP 1/170: Guidelines for the efficacy evaluation of plant protection products: sideeffects on honeybees. Appendix I, in: Belzunces L.P., Pélissier C., Lewis G.B. (Eds.), Hazards of pesticides to bees, Les Colloques de l'INRA, $\mathrm{n}^{\circ}$ 98, Paris, pp. 279-288.

Patetta A., Marletto F., Manino A. (2002) Pesticides and bumblebees: poisoning tests in the laboratory, Insect Soc. Life 4, 101-106.

Peach M.L., Tepedino V.J., Alston D.G., Griswold T.L. (1993) Insecticide treatments for rangeland grasshoppers: potential effects on the reproduction of Pediocactus sileri (Englem.) Benson (Cactaceae), pp. 309-319, in: Sivinski R., Lightfoot K. (Eds.), Proc. Southwestern Rare and Endangered Plant Conf., Santa Fe, NM.

Richards K.W. (1984) Alfalfa leafcutter bee management in Western Canada, Agriculture Canada Publication 1495/E, Ottawa, Canada.

SAS Institute Inc. (1989) SAS/STAT User's guide, Version 6. Cary, NC.

Solomon M.G., Hooker K.J.M. (1989) Chemical repellents for reducing hazard to honeybees in apple orchards, J. Apic. Res. 28, 223-227.

Southwick E.E., Southwick L. (1992) Estimating the economic value of honey bees (Hymenoptera: Apidae) as agricultural pollinators in the United States, J. Econ. Entomol. 85, 621-633.

Taséi J.N. (2002) Impact of agrochemicals on nonApis bees, in: Devillers J., Pham-Delègue M.-H. (Eds.), Honey bees: estimating the environmental impact of chemicals, Taylor \& Francis, London, pp. 101-131.

Tepedino V.J., Ginsberg H.S. (2000) Report of the US Department of Agriculture and US Department of the Interior joint workshop on declining pollinators. Information and Technology Report USGS/ BRD/ITR 2000-0007, Fort Belvoir, VA.

Thompson H.M. (2003) Behavioural effects of pesticides in bees - their potential for use in risk assessment, Ecotoxicol. 12, 317-330.

US EPA (1996) Honey bee acute contact toxicity test (OPPTS 850.3020). Ecological effects test guidelines, EPA 712-C-96-147, Washington, DC.

van der Steen J.J.M., Gretenkord C., Schaeffer H. (1996) Methods to determine acute oral and contact LD50 of pesticides for bumblebees (Bombus terrestris L.), Appendix 28, in: Lewis G. (Ed.), Proc. VIth Int. Symp. on Hazards of pesticides to bees, Braunschweig. 